\title{
STUDY ON EXPRESSION OF CYTOKINE GENES IN PERIPHERAL BLOOD MONONUCLEAR CELLS (PBMCS) FOLLOWING HEPATITIS B VACCINATION
}

\author{
Dr. Marufa Hossain ${ }^{1}$, Dr. Omma Hafsa Any ${ }^{2}$, Dr. Rezina Sultana ${ }^{3}$, Dr. Farjana Majid ${ }^{4}$, Dr. Nashid Tabassum Khan ${ }^{5}$ \\ ${ }^{1}$ Assistant Professor of Microbiology, Z.H. Sikder Women's Medical College, Dhaka \\ ${ }^{2}$ Assistant Professor of Pharmacology, Z.H. Sikder Women's Medical College, Dhaka \\ ${ }^{3}$ Assistant Professor of Pharmacology, Z.H. Sikder Women's Medical College, Dhaka \\ ${ }^{4}$ Assistant Professor of Microbiology, Tairunnessa memorial Medical College,Gazipur, Dhaka \\ ${ }^{5}$ Assistant Professor of Forensic Medicine, Z.H. Sikder Women's Medical College, Dhaka
}

\begin{abstract}
Vaccination with surface protein of Hepatitis B Virus (HBSAg) is considered the main strategy for effective control of the infection and viral transmission. The present study was designed to determine the expression of Interferon (INF-y) in peripheral blood mononuclear cells (PBMCS) by RT-PCR method. In the present study, PBMCs from responders expressed INF- $y$ gene in response to HBSAg, while nonresponders expressed low levels of this cytokines. Most humoral non responders to HBV thus develop specific cellular immune responses, eventually liable to protect them against viral infection.
\end{abstract}

Keywords: Hepatitis B vaccine, RT-PCR, INF-V, Cytokine, Gene.

(Bangladesh J Physiol Pharmacol 2013(1\&2): 25-28)

\section{INTRODUCTION}

Bangladesh is a moderately endemic country for chronic hepatitis $\mathrm{B}(\mathrm{CHB})$ infection. $^{1}$ If standard vaccination practices are followed, most individuals will mount an anti-HBs response which is sufficient to prevent HBV infection. ${ }^{2}$ In 1991, the World Health Organization (WHO) recommended that hepatitis B vaccination should be included in the national immunization program for all countries with a hepatitis B carrier prevalence of $8 \%$ or greater by 1995 and in all other countries by $1997 .{ }^{3}$ The result of this worldwide implementation of hepatitis $B$ vaccination is a reduction of acute and chronic hepatitis B infections. At present, in Bangladesh, hepatitis B vaccination has been started by incorporating it into the existing Expanded Program of Immunization (EPI) schedule from late 2004. ${ }^{4}$ Presently, recombinant DNA vaccines are available with an efficacy of more than $95 \%$ among children and $90 \%$ among normal healthy individuals. ${ }^{5}$ Post vaccination testing for antibody titer is done to detect the response of vaccine. Development of anti-HBs antibodies (minimum level of $10 \mathrm{mIU} / \mathrm{ml}$ ) is considered as protective immunity. ${ }^{6}$ Most individuals develop antibody titer $>100 \mathrm{mIU} / \mathrm{ml}$ within 6-8 weeks after completing the vaccine series and are labeled as responders. Some apparently healthy individuals do not show an anti-HBs antibody response or respond poorly to the surface

Address for correspondence: Dr. Marufa Hossain, Assistant Professor of Microbiology, Z.H. Sikder Women's Medical College, Dhaka. E-mail: drmarufa@yahoo.com Mob:01911190813 antigen component (HBsAg), and are labeled as nonresponders and poor responders or hypo-responders with antibody titer $<10 \mathrm{mIU} / \mathrm{ml}$ and $10-100 \mathrm{mIU} / \mathrm{ml}$ respectively. ${ }^{7}$ It is estimated that about $5-15 \%$ of the vaccinee may be non responders. ${ }^{8}$ However, dose, storage, sites and routes of administration, gender, genetic factor, obesity, diabetes, and immunosuppression can all adversely affect the immune response. ${ }^{9-11}$ The antibody against $\mathrm{HBsAg}$ is produced by $\mathrm{B}$ cell after $\mathrm{TH}$ cell activation. Therefore defective cytokine response, either Th1 or Th2, may result in failure of immune response to this antigen. Present study reports expression of TH1 cytokines IFN- $\gamma$ gene following hepatitis $B$ vaccination.

\section{MATERIALS AND METHODS \\ SUBJECTS SELECTION:}

The study was carried out among of 45 vaccine recipients (15 responders, 15 poor responders, 15 non responders) and 15 healthy unvaccinated individuals at the Department of Virology, Bangabandhu Sheikh Mujib Medical University (BSMMU) from January 2012 to July 2012. The study population was divided into four groups according to their Anti-HBs titer (responder, poor responder, non-responder and unvaccinated individuals). Their ages ranged from 21 to 59 years (mean age: $35.82 \pm 9.49$ years). Blood samples were collected 6-8 weeks after a full-course $(0,1$ and 6 month regimen) of hepatitis $B$ vaccination. 


\section{IN VITRO STIMULATION OF PBMC WITH HEPATITIS B VACCINE ANTIGEN:}

For each test, $5 \mathrm{ml}$ of peripheral blood were collected on EDTA and Peripheral blood mononuclear cells (PBMC) were isolated by density gradient centrifugation in sterile conditions, and then washed in sterile RPMI 1640 medium. Isolated PBMCs were adjusted to $1 \times 10^{6}$ cells $/ \mathrm{ml}$ and was suspended into $1 \mathrm{ml}$ complete culture media which was prepared by RPMI1640 supplemented with $100 \mathrm{IU} / \mathrm{ml}$ penicillin, $100 \mu \mathrm{g} / \mathrm{ml}$ streptomycin, $25 \mu \mathrm{g} / \mathrm{ml}$ amphotericine-B and $10 \%$ heat inactivated fetal bovine serum with $25 \mathrm{mmol} / \mathrm{l}$ HEPES buffer. Then, $500 \mu \mathrm{l}$ PBMCs were transferred in a 6 well sterile tissue culture plate with presence or absence of $5 \mu \mathrm{g} / \mathrm{ml}$ of HB vaccine (Engerix B $20 \mu \mathrm{g} / \mathrm{ml}$ ) ${ }^{12}$ and the plates were incubated in humidified air containing $5 \%$ $\mathrm{CO}_{2}$ at $37^{\circ} \mathrm{C}$ in $\mathrm{CO}_{2}$ incubator. After 72 hours, nonadherent cells and supernatant were removed from culture plates and centrifuged at 1200 RPM for 5 mins. ${ }^{13}$ Then, cell pellets were collected for mRNA extraction.

\section{CYTOKINE MRNA DETERMINATION: SEMIQUANTITATIVE RT-PCR:}

Total RNA was isolated from the cell pellets with a commercially available kit (Geneaid Total RNA mini kit) according to the manufacturer's instruction followed by RT-PCR. Each reaction contained primers specific for beta actin (house keeping gene) and cytokines. PCR products for each reaction were run on a $2.5 \%$ agarose gel for cytokines and $4 \%$ for housekeeping genes. DNA bands were visualized using Wealtec Dolphin View gel imaging system (U.S.A.) and intensities of bands were measured using Image J software.

\section{DATA ANALYSIS:}

Results were expressed as mean \pm standard deviation (SD) or percentage. ANOVA \& paired t test were done for comparison. Statistical analysis was made using SPSS 17.0 software, and $p$ value of $<0.05$ considered as statistically significant.

\section{RESULT}

\section{EXPRESSION OF CYTOKINES}

PBMCs from all subjects tested proliferated in response to HBsAg antigen were higher than the PBMCs from without stimulation (Table-I). Various patterns of the cytokine expression were observed depending on the individuals (Fig-1). In this study, in responder group, after stimulation with HBsAg, IFN- $\gamma$ gene expression was $2.49 \pm 0.73$ fold and without stimulation it was $1.02 \pm 0.33$ fold $(p>0.05)$. In poor responder group, IFN-y gene expression was $1.87 \pm 0.60$ fold with HBsAg stimulation, while without stimulation this was $1.06 \pm 0.20$ fold $(p<0.05)$. After stimulation with $\mathrm{HBsAg}$ antigen, IFN- $\gamma$ gene expression in non-responder group was $1.55 \pm 0.49$ fold, and without stimulation this was $1.05 \pm 0.22$ fold $(p<0.05)$. In unvaccinated group, after stimulation with $\mathrm{HBsAg}$, IFN- $\gamma$ gene expression was $1.07 \pm 0.29$ fold, but without stimulation this was $0.97 \pm 0.55$ fold, $p>0.05$ (Fig-1).

Table 1

Expression of different cytokines (Mean $\pm S D$ ) among study population after stimulation with or without $\mathrm{HBSAg}$

\begin{tabular}{llllll}
\hline Cytokine & Stimulation & Responder & $\begin{array}{c}\text { Poor } \\
\text { responder }\end{array}$ & $\begin{array}{c}\text { Non } \\
\text { responder }\end{array}$ & unvaccinated \\
\hline $\boldsymbol{I} \boldsymbol{F} \boldsymbol{N}-\boldsymbol{r}$ & With HBsAg & $2.49 \pm 0.73$ & $1.87 \pm 0.60$ & $1.55 \pm 0.49$ & $1.07 \pm 0.29$ \\
& No stimulation & $1.02 \pm 0.33$ & $1.06 \pm 0.20$ & $1.05 \pm 0.22$ & $0.97 \pm 0.55$ \\
& P value & 0.020 & 0.005 & 0.017 & 0.566 \\
\hline
\end{tabular}

Figure-1

Mean expression of IFN- $y$ gene in different groups. In the left side of the figure shows expression of $\beta$ actin gene in agarose gel (lower) and expression of IFN- $\gamma$ gene in agarose gel (upper) in corresponding groups.

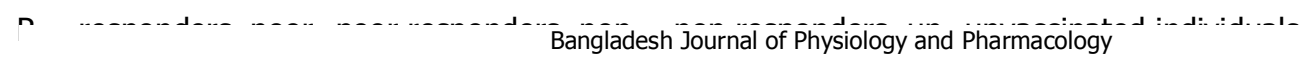

ANOVA test was done.

$P<0.05$ indicates statistical significance.

Paired t test was done. 

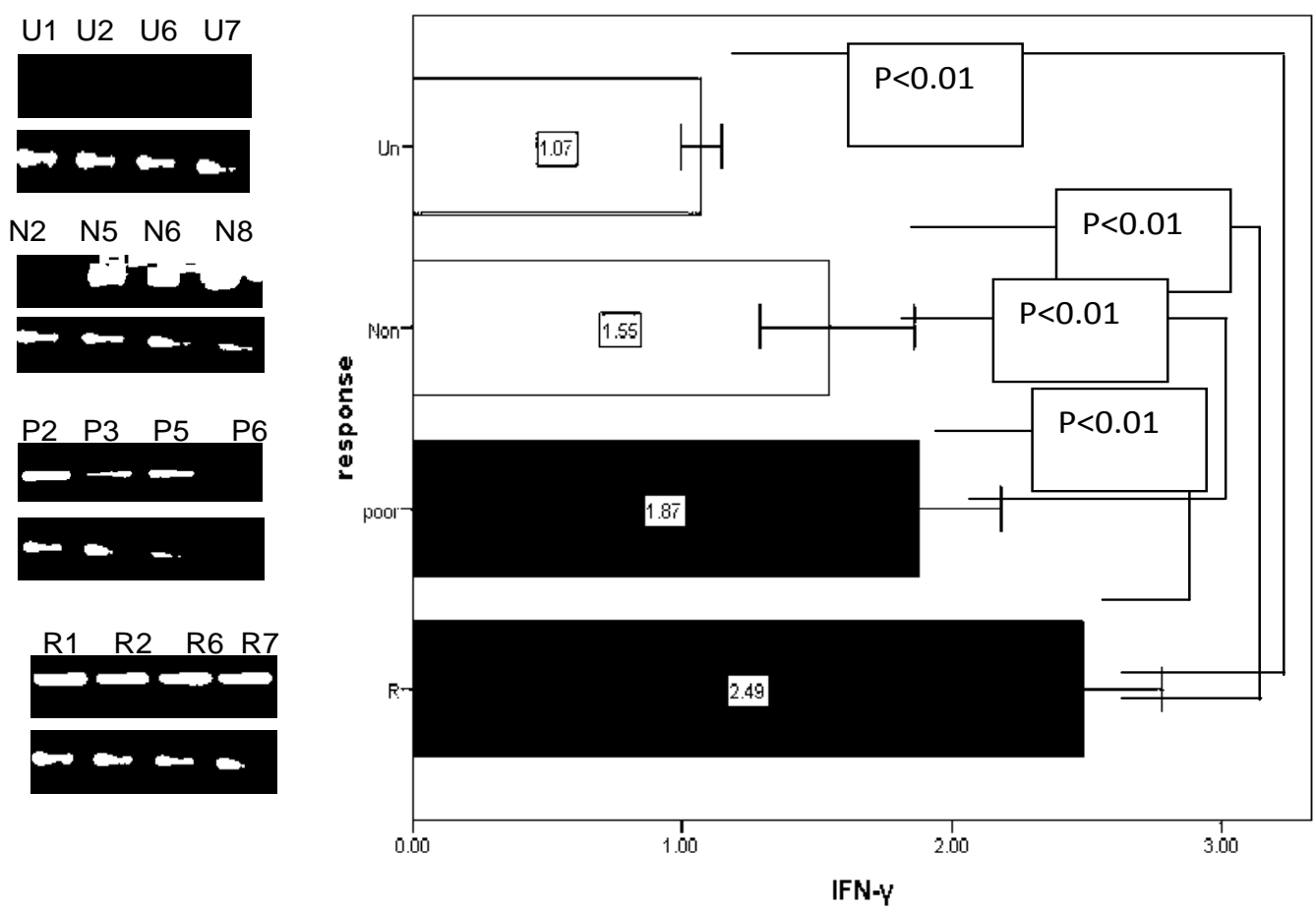

\section{DISCUSSION}

Universal HBV immunization programs for both infants and adolescents are associated with dramatic decline in the incidence and prevalence of HBV infection. After vaccination, protective immune response correlates with detectable humoral response in vivo (Anti $\mathrm{HBsAg}$ ) and cellular response in vitro which is dependent on cytokine secretion profile of activated $T$ lymphocytes. A study from Bangladesh, observed that $90 \%-95 \%$ adults are good responders after completion of the full vaccination regime. ${ }^{14}$ Induction of HBsAg specific antibody requires proper secretion of TH1 or TH2 cytokines leading to maturation and differentiation of the HBsAg-specific B-cell clones. Therefore, improper secretion of cytokines may result in failure of the expected immune response. However, the pattern of cytokine production in response to $\mathrm{HBsAg}$ stimulation may provide some clue to understand the unresponsiveness against hepatitis $B$ vaccine. Thus, the present study evaluated the TH1/TH2 cytokine levels in healthy adults vaccinated with recombinant hepatitis B vaccine in order to better understand the immune response among Bangladeshi population. In the present study, after stimulation with HBsAg, expression of IFN-y gene in PBMCs were analyzed by RT-PCR. The overall
TH1 gene expression are up regulated in vaccine responders compared to other groups in the present study after 72 hours stimulation with HBsAg. In this study, vaccine responders expressed higher level ( $2.49 \pm 0.73$ fold) of IFN- $\gamma$ compared to other groups. This result was similar to another study that revealed non responders produced less amount of IFN- $Y$ detected by PCR. ${ }^{12}$ Another study using ELISA observed that non-responders did not secrete IFN- $y$ in response to HBsAg. ${ }^{16}$ In the present study, IFN- $Y$ was less expressed in PBMCs of non-responder whereas, most of the PBMCs from responders expressed IFN- $y$ when stimulated with HBsAg. The majority of the responders included in this study had anti-HBs titer $>2000 \mathrm{mIU} / \mathrm{ml}$. Of these, all PBMCs did not express equal quantity of IFN- $\gamma$, some expressed poorly, and some strongly expressed IFN- $y$ toward HBsAg in vitro. Previously, one study reported that nonresponse is due to defect of TH1 cytokine. ${ }^{17-18}$ In the present study, unvaccinated individual expressed less amount $1.07 \pm 0.29$ fold IFNY compared to responder. Due to primary immunization this may be attributed to the fact that in unvaccinated individuals if they are vaccinated they may produce sufficient amounts of immune response against HBsAg. 


\section{CONCLUSION}

From the present study, it may be suggested that cellular parameter should also be considered along with serological indicators as a marker of protection. In future, in addition to the serum levels of anti-HBs antibody, the profile of cytokine secretion may also be used as a distinctive parameter to identify hepatitis B vaccine responder and non-responder individuals.

\section{REFERENCES}

1. Alam S, Ahmad N, Mustafa G, Alam K, Khan M. Characteristics of treatment naive chronic hepatitis $B$ in Bangladesh: Younger populations are more effected; $\mathrm{E}$ antigen negatives are more advanced. Saudi J Gastroenterol 2008; 14:15-19.

2. Atkintson $\mathrm{WL}$, Pickering $\mathrm{LK}$, Schwartz B. General recommendations on immunization. Recommendations of the advisory committee on immunization practices (ACIP) and the American Associations of Family Physicians (AAFP). MMWR Recomm Rep 2002; 55: 1- 35.

3. Ahad MA, Alim MA, Guho A, Islam QT, Azad KAK. Role of booster dose on antibody titer after recombinant hepatitis $B$ vaccination. J Med 2009; 10: 67-76.

4. Rashid $\mathrm{H}$, Rafiq SM. Hepatitis B vaccination in Bangladesh:a suggestion based on current evidence. Hepatitis Monthly 2006; 6(1): 41-44

5. Bowes M. Pathways of controlling Hepatitis A and B: Vaccination, Prevention and Treatment. American Academy of Family Physicians 2003

Available at: www.cepis.ops-oms.org/bvsacd/cd49/ hepatitis2004.pdf Accessed April 22, 2009.

6. Mahoney FJ. Update on Diagnosis, Management, and Prevention of Hepatitis B Virus Infection. Clin Microbiol Rev 1999; 12(2): 351-366.

7. Zuckerman AJ. Hepatitis Viruses. In: Baron S, eds. Medica Microbiology 1996, 4th ed. The University of Texas Medical Branch at Galveston, 849-863.

8. Zuckerman JN, Sabin C, Craig FM. Immune response to a new hepatitis $B$ vaccine in healthcare workers who had not responded to standard vaccine: randomised blind dose- response study. $\mathrm{Br}$ Med J 1997; 314: 329 - 33.

9. Hollinger $\mathrm{EB}$, Kim $\mathrm{CN}$, Lee HU. Factor influencing the immune response to hepatitis B Vaccine, booster dose Guideline and vaccine Protocol recommendation. Am J Med 1989; 16: 365-403.

10. Wood RC, MacDonald KL, White KE, Hedbertn GW, Harrison M. Risk factor for lack of detectable antibody following hepatitis $B$ vaccination of Minnesota Health care workers. JAMA 1993; 270 2935-2939.

11. Roome AJ, Walsh S, Cartter M, Hadler J. Hepatitis B vaccine responsiveness in Connecticut public safety personnel. JAMA 1993; 270 (24): 2931-2934.

12. Jarrosson $L$, Kolopp-Sarda $M N$, Aguilar $P$, Bene $M C$, Lepori ML, Vignaud $M C$, et al. Most humoral non-responders to hepatitis $B$ vaccines develop HBV-specific cellular immune responses. Vaccine 2004; 22: 3789-3796.

13. Vijayakumar $V$, Saravanan $S$, Nandakumar $S$, Shankar EM, Vengatesan A, Jadhav SS. Relationship between T-lymphocyte cytokine levels and sero-response to hepatitis B vaccines. World J Gastroenterol 2008; 14(22): 3534-3540.

14. Rashid H, Rafiq SM. Hepatitis B vaccination in Bangladesh: a suggestion based on current evidence. Hepatitis Monthly 2006; 6(1): 41-44.
15. Fan J, Nishanian P, Breen EC, Mcdonald M, Fahey JL. Cytokine gene expression in normal human lymphocytes in response to stimulation. Clin Diagn Lab Immunol 1998; 5(3): 335-340.

16. Larsen $C E, X u ~ J$, Lee S, Dubey DP, Uko G, Yunis EJ, et al. Complex cytokine responses to hepatitis $B$ surface antigen and tetanus toxoid in responders, nonresponders and subjects naive to hepatitis B surface antigen. Vaccine 2000; 18: 3021-3030.

17. Chedid MG, Deulofeut H, Yunis DE, Lara-Marquez ML, Salazar M, Deulofeut $R$, et al. Defect in Th1-like cells of nonresponders to hepatitis B vaccine. Hum Immunol 1997; 58: 42-51.

18. Kardar G, Tehrani J, Shokri F. Diminished Th1 and Th2 cytokine production in healthy adult nonresponders to recombinant hepatitis B vaccine. Scand J Immunol 2002; 55, 311 -314. 